\title{
Phosphorylation of HSF1 at serine 326 residue is related to the maintenance of gynecologic cancer stem cells through expression of HSP27
}

\author{
Kazuyo Yasuda ${ }^{1}$, Yoshihiko Hirohashi ${ }^{1}$, Tasuku Mariya ${ }^{1,2}$, Aiko Murai ${ }^{1}$, Yuta \\ Tabuchi $^{1,2}$, Takafumi Kuroda2, Hiroki Kusumoto ${ }^{1}$, Akari Takaya ${ }^{1}$, Eri Yamamoto ${ }^{1}$, \\ Terufumi Kubo ${ }^{1}$, Munehide Nakatsugawa ${ }^{1}$, Takayuki Kanaseki ${ }^{1}$, Tomohide \\ Tsukahara1 $^{1}$ Yasuaki Tamura ${ }^{1}$, Hiroshi Hirano ${ }^{3}$, Tadashi Hasegawa ${ }^{3}$, Tsuyoshi \\ Saito $^{2}$, Noriyuki Sato ${ }^{1}$, Toshihiko Torigoe ${ }^{1}$ \\ ${ }^{1}$ Department of Pathology, Sapporo Medical University School of Medicine, Chuo-Ku, Sapporo 060-8556, Japan \\ ${ }^{2}$ Department of Obstetrics and Gynecology, Sapporo Medical University School of Medicine, Chuo-Ku, Sapporo 060-8556, \\ Japan \\ ${ }^{3}$ Department of Surgical Pathology, Sapporo Medical University School of Medicine, Chuo-Ku, Sapporo 060-8556, Japan \\ Correspondence to: Toshihiko Torigoe, email: torigoe@sapmed.ac.jp \\ Yoshihiko Hirohashi, email: hirohash@sapmed.ac.jp
}

Keywords: gynecological cancer, cancer stem cell, stress response, HSP27, HSF1

Received: February 10, 2016

Accepted: March 10, 2017

Published: March 18, 2017

Copyright: Yasuda et al. This is an open-access article distributed under the terms of the Creative Commons Attribution License (CC-BY), which permits unrestricted use, distribution, and reproduction in any medium, provided the original author and source are credited.

\section{ABSTRACT}

Cancer stem-like cells (CSCs)/ cancer-initiating cells (CICs) are defined by their higher tumor-initiating ability, self-renewal capacity and differentiation capacity. CSCs/CICs are resistant to several therapies including chemotherapy and radiotherapy. CSCs/CICs thus are thought to be responsible for recurrence and distant metastasis, and elucidation of the molecular mechanisms of CSCs/CICs are essential to design CSC/CIC-targeting therapy. In this study, we analyzed the molecular aspects of gynecological CSCs/CICs. Gynecological CSCs/CICs were isolated as ALDH1 ${ }^{\text {high }}$ cell by Aldefluor assay. The gene expression profile of CSCs/CICs revealed that several genes related to stress responses are preferentially expressed in gynecological CSCs/ CICs. Among the stress response genes, a small heat shock protein HSP27 has a role in the maintenance of gynecological CSCs/CICs. The upstream transcription factor of HSP27, heat shock factior-1 (HSF1) was activated by phosphorylation at serine 326 residue (pSer326) in CSCs/CICs, and phosphorylation at serine 326 residue is essential for induction of HSP27. Immunohistochemical staining using clinical ovarian cancer samples revealed that higher expressions of HSF1 pSer326 was related to poorer prognosis. These findings indicate that activation of HSF1 at Ser326 residue and transcription of HSP27 is related to the maintenance of gynecological CSCs/CICs.

\section{INTRODUCTION}

In various organs, the histological architectures are systematized by a hierarchical differentiation model. Stem cells are located on the top of hierarchical differentiation model and are defined as subpopulation having selfrenewal ability and capacity of differentiation into mature cells that can repopulate specific tissues and specific organs [1]. Likewise, cancer stem cells with similar characters of stem cells had long been hypothesized. The outline of cancer stem cells that we have referred to as cancer stem-like cells $(\mathrm{CSCs}) /$ cancer-initiating cells (CICs) was proposed in the 1960's [2,3], and the framework of $\mathrm{CSCs} / \mathrm{CICs}$ is thought to be very similar to that of normal stem cells. In 1994, John Dick and colleagues reported in their historical work that human acute myeloid leukemia is organized in a hierarchical differentiation model, and $\mathrm{CD} 34^{+} \mathrm{CD} 38^{-}$cells are the stem cells of this model and only $\mathrm{CD} 34^{+} \mathrm{CD} 38^{-}$cells can regenerate the disease [4]. In the following works, $\mathrm{CSCs} / \mathrm{CICs}$ were also isolated from several solid malignancies including breast cancer, lung cancer, colon cancer and prostate cancer, and CSC 
model is well accepted in human malignancies [5]. CSCs/ CICs are now defined as a small subpopulation of cancer cells that are endowed with 'self renewal capacity', 'differentiation capacity' and 'higher tumorigenicity' [2]. CSCs/CICs may contribute to tumor recurrence and metastasis by their resistance to chemotherapy-radiation therapy and cytotoxic chemotherapy [6]. Therefore eradication of $\mathrm{CSCs} / \mathrm{CICs}$ is indispensable for radical cancer treatment.

A stress responsive system including heat shock proteins (HSPs) are protective mechanism for various types of stress and is conserved in that all cells are equipped with [7]. All living organisms on earth including humans are constantly exposed to stresses, such as active oxygen, warm temperature and low oxygen. Despite the severe environment, all organisms from sea-squirts to humans have the ability to survive because of the innate acquisition of a stress-responsive system. Normal stem cells are endowed with stress resistance to survive the stress and can regenerate the organ under stress conditions [8]. Recent studies revealed that CSCs/CICs like normal stem cells have distinctive stress-responsive systems compared with differentiated non-CSCs/CICs, and stress-responsive mechanisms are related to malignant phenotypes indicating the relation between stress response mechanisms and CSCs/CICs [9-14].

In present study, we performed transcriptome analysis of gynecological CSCs/CICs using a cDNA microarray, and found that a stress-responsive gene HSP27 is preferentially expressed in CSCs/CICs, that might be induced by constitutive activation of heat shock factor-1 (HSF1) by phosphorylation at serine 326 residue.

\section{RESULTS}

\section{Isolation of CSCs/CICs from gynecological cancers}

In the previous studies, we confirmed that CSCs/ CICs were enriched in $\mathrm{ALDH}^{\text {high }}$ population from ovarian cancer line cells $[15,16]$. To analyze the molecular aspects of CSCs/CICs in gynecologic cancers, we isolated $\mathrm{ALDH}^{\text {high }}$ cells from endometrioid adenocarcinoma line cell HEC-1 to isolate CSCs/CICs. The rate of $\mathrm{ALDH}^{\text {high }}$ cells was $8.9 \%$ by Aldefluor assay (Figure 1A). To confirm that CSCs/CICs were enriched in $\mathrm{ALDH}^{\text {high }}$ cells, a sphere forming assay, xenograft transplantation and RTPCR analysis were performed. ALDH ${ }^{\text {high }}$ cells derived from HEC-1 cells showed significant higher sphereformation in floating condition than that of $\mathrm{ALDH}^{\text {low }}$ cells (Figure 1B). To address the in vivo tumor-initiating ability of $\mathrm{ALDH}^{\text {high }}$, we injected $10^{2}, 10^{3}$ and $10^{4}$ of $\mathrm{ALDH}^{\text {high }}$ cells and $\mathrm{ALDH}^{\text {low }}$ cells derived from HEC-1 cells into NOD/SCID mice. Tumor initiation was observed in 5 of 11 mice injected with $10^{3}$ of $\mathrm{ALDH}^{\text {high }}$ cells and 10 of 11 mice injected with $10^{4}$ of $\mathrm{ALDH}^{\text {high }}$ cells (Table 1 ). The estimated CSC/CIC frequency in $\mathrm{ALDH}^{\text {high }}$ cells was 1 in 3082 cells. On the other hand, tumor initiation was observed in 1 of 11 mice injected with $10^{3}$ of $\mathrm{ALDH}^{\text {low }}$ cells and 4 of 11 mice injected with $10^{4}$ of ALDH $^{\text {low }}$ cells. The estimated CSC/CIC frequency in $\mathrm{ALDH}^{\text {low }}$ cells was 1 in 19987. No tumor initiation was observed in $10^{2}$ of $\mathrm{ALDH}^{\text {high }}$ cell and $\mathrm{ALDH}^{\text {low }}$ cell injections. The difference of estimated $\mathrm{CSC} / \mathrm{CIC}$ frequency was statistically significant $(P=0.000258)$ (Table 1$)$. The tumors derived from $10^{4}$ of ALDH $1^{\text {high }}$ cells grew statistically significantly faster than those derived from ALDH ${ }^{\text {low }}$ cells (Figure 1C). Similar difference of tumor-initiation was observed in MCAS cells and HTBoA cells (Table 1). Tumors derived from $\mathrm{ALDH}^{\text {high }}$ and $\mathrm{ALDH}^{\text {low }}$ cells in HEC-1 and MCAS cells showed no notable histological difference. We then performed immunohistochemical staining using anti-ALDH1 antibody to determine the ALDH1 protein expression in tumors derived from $\mathrm{ALDH}^{\text {high }}$ and $\mathrm{ALDH}^{\text {low }}$ cells. The tumors derived from ALDH ${ }^{\text {high }}$ cells showed higher positivity to anti-ALDH1 antibody than that in the tumors derived from ALDH ${ }^{\text {low }}$ cells (Figure 1D). ALDH ${ }^{\text {high }}$ cells showed higher expressions of stem cell-related genes (ALDH1, SOX2, POU5F1 and NANOG) at higher levels than $\operatorname{did} \mathrm{ALDH}^{\text {low }}$ cells (Figure 1E). These results indicate that $\mathrm{ALDH}^{\text {high }}$ cells derived from HEC-1 cells are enriched with CSCs/CICs. In our previous study, we showed that $\mathrm{ALDH}^{\text {high }}$ cells from ovarian cancer line cells MCAS and HTBoA were also enriched with CSCs/CICs $[16,17]$. We therefore further analyzed ALDH ${ }^{\text {high }}$ cells derived from HEC-1, MCAS and HTBoA cells to address the molecular insight of gynecological CSCs/CICs.

\section{Stress responsive genes are expressed in ALDH $^{\text {high }}$ cells}

To analyze the molecular mechanisms of ALDH ${ }^{\text {high }}$ cells, we screened ALDH ${ }^{\text {high }}$ cell-specific genes using a cDNA microarray. The summary of up-regulated genes in $\mathrm{ALDH}^{\text {high }}$ cells derived from HEC-1 cells is shown in Supplementary Table 2. Interestingly, several genes involved in stress response are expressed in ALDH ${ }^{\text {high }}$ cellspecific expression. The expressions of HSP27 mRNA in $\mathrm{ALDH}^{\text {high }}$ and $\mathrm{ALDH}^{\text {low }}$ cells derived from HEC1, MCAS and HTBoA were confirmed by qRT-PCR (Figure 2A). HSP27 protein expressions in the tumors derived from $\mathrm{ALDH}^{\text {high }}$ cells were examined by immunohistochemical staining using anti-HSP27 antibody. The tumors derived from $\mathrm{ALDH}^{\text {high }}$ cells derived from HEC- 1 cells and MCAS cells showed higher expressions of HSP27 protein than those in tumors derived from ALDH ${ }^{\text {low }}$ cells (Figure 2B). To confirm HSP27 protein expressions in clinical samples, immunohistochemical staining using human ovarian cancer specimens $(n=122)$ were performed. Ovarian cancer cases showed positive staining for HSP27, and we categorized the cases into 3 groups (score $0:<15 \%, n=40$; score 1: $15 \%-30 \%, n=41$; score 2 : $>30 \%, n=41$ ) 
Table 1: Tumor-initiating ability of endometrial cancer cell and ovarian cancer cells

\begin{tabular}{|c|c|c|c|c|c|c|c|}
\hline & \multirow{2}{*}{ Cells } & \multicolumn{3}{|c|}{ Injected cell number } & \multirow[b]{2}{*}{ CSC frequency } & \multirow[b]{2}{*}{$95 \% \mathrm{CI}$} & \multirow[b]{2}{*}{$P$ value } \\
\hline & & $10^{2}$ & $10^{3}$ & $10^{4}$ & & & \\
\hline \multirow{5}{*}{ HEC-1 } & $\mathrm{ALDH}^{\text {high }}$ cells & $0 / 11$ & $5 / 11$ & $10 / 11$ & 1 in 3082 & $1546-6145$ & \multirow{5}{*}{$* 0.000258$} \\
\hline & $\mathrm{ALDH}^{\text {low }}$ cells & $0 / 11$ & $1 / 11$ & $4 / 11$ & 1 in 19987 & $8195-48748$ & \\
\hline & control siRNA & - & $3 / 5$ & - & & & \\
\hline & HSF1 siRNA-i & - & $0 / 5$ & - & & & \\
\hline & HSF1 siRNA-ii & - & $0 / 5$ & - & & & \\
\hline \multirow{2}{*}{ MCAS } & $\mathrm{ALDH}^{\text {high }}$ cells & $0 / 5$ & $0 / 5$ & $5 / 5$ & 1 in 4326 & $1640-11415$ & \multirow{2}{*}{0.0519} \\
\hline & $\mathrm{ALDH}^{\text {low }}$ cells & $0 / 5$ & $0 / 5$ & $2 / 5$ & 1 in 22379 & $5622-89084$ & \\
\hline \multirow{2}{*}{ НTBoA } & $\mathrm{ALDH}^{\text {high }}$ cells & $0 / 5$ & $0 / 5$ & $3 / 5$ & 1 in 12859 & 4134-39996 & \multirow{2}{*}{$* 0.0214$} \\
\hline & $\mathrm{ALDH}^{\text {low }}$ cells & $0 / 5$ & $0 / 5$ & $0 / 5$ & - & $18527-$ & \\
\hline
\end{tabular}

The tumor-initiating abilities were evaluatad at day 70 post cell injection. Data are expressed as number of tumors formed/ number of injections. Differences of estimated frequencies of CICs were analyzed by Chi-square test. CSC frequencies were calclutated at ELDA web site (http://bioinf.wehi.edu.au/software/elda/). $* P<0.05$.

A

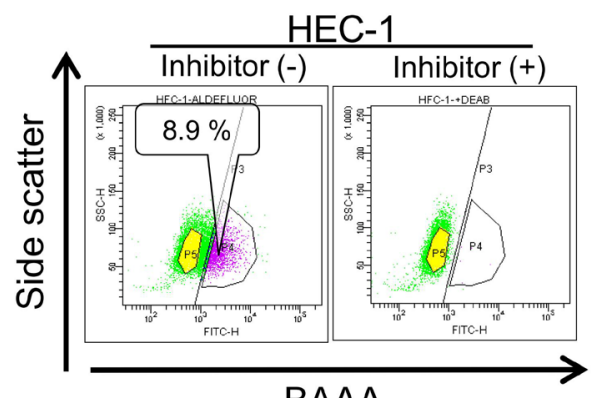

BAAA

$\mathrm{D}$

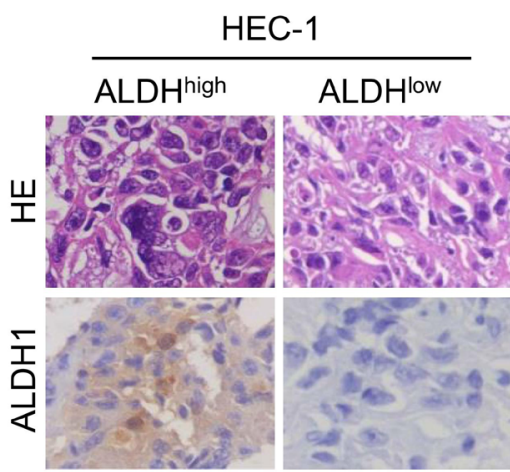

$\mathrm{B}$
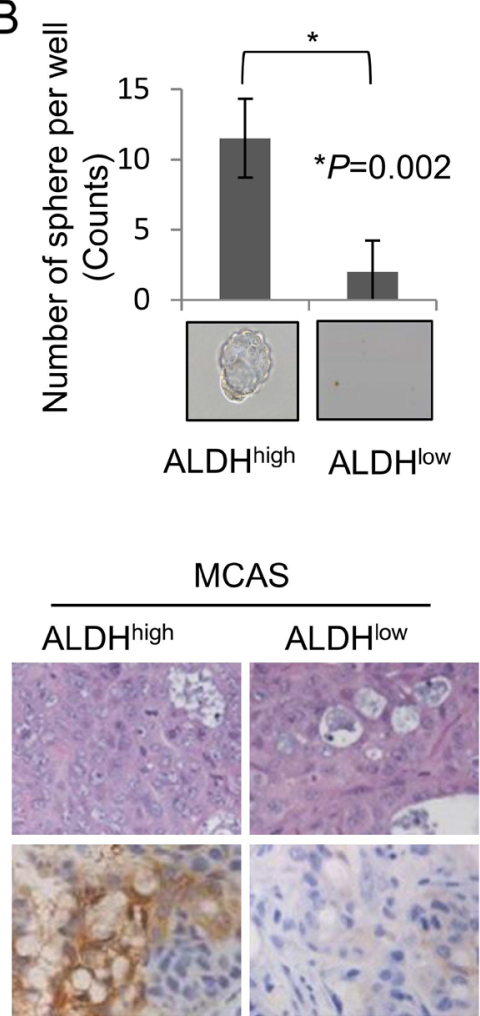

C

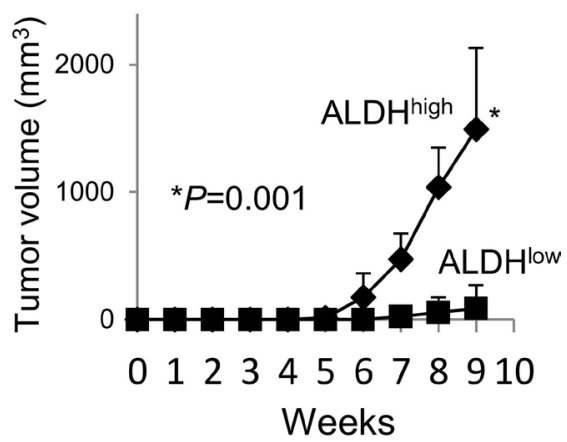

$E$

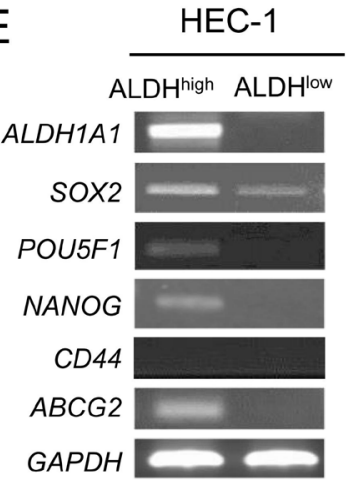

Figure 1: Isolation of CSCs/CICs from HEC-1 cells by Aldefluor assay. (A) Detection of ALDH1high cells. ALDH1 ${ }^{\text {high }}$ cells were isolated using HEC-1 cell. Percentage represents the proportion of ALDH1 ${ }^{\text {high }}$ cells. (B) Representative picture of tumor sphere. ALDH $1^{\text {high }}$ and ALDH $1^{\text {low }}$ cells derived from HEC-1 cells were cultured in CSC Certified ${ }^{\mathrm{TM}}$ Complete Serum-Free Medium. After 2 weeks of culture in vitro, a picture of a tumor sphere was taken and sphere numbers were counted. Data represent means \pm SD. (C) Tumor formation ability of HEC-1 ALDH1high and ALDH1low cells. ALDH1 ${ }^{\text {high }}$ and ALDH1 $1^{\text {low }}$ cells derived from HEC-1 cells were inoculated into the backs of NOD/SCID mice subcutaneously with serial dilution $\left(10^{2}-10^{4}\right)$. Graphs show the tumor growth curves of ALDH1 high and ALDH $1^{\text {low }}$ injected groups with injections of $10^{4}$ cells. Data represent means \pm SD. Differences between ALDH1 ${ }^{\text {high }}$ cells and ALDH1 ${ }^{\text {low }}$ cells were examined for statistical significance using Student's $t$-test. * $P$ value. (D) Histology of ALDH1high cell-derived and and ALDH1low cell-derived tumors. Tumors derived from ALDH1 ${ }^{\text {high }}$ and ALDH1 ${ }^{\text {low }}$ cells in HEC-1 and MCAS cells were stained by hematoxylin and eosin and immunostained by ALDH1 antibody. Magnification $\times 200$. (E) Expressions of stem cell markers by RT-PCR analysis. ALDH1 ${ }^{\text {high }}$ and ALDH1 ${ }^{\text {low }}$ cells derived from HEC-1 cells were examined for expression of stem cell markers (SOX2, POU5F1, NANOG, CD44 and ABCG2). GAPDH was used as an internal control. 
according to the positivity for HSP27 staining (Figure 2C). Lower HSP27 staining (score 0) showed relative better prognosis than that with higher HSP27 staining (score $1+$ score 2); however, the difference did not reach statistical significance $(P=0.249)$ (Figure $2 \mathrm{D})$.

\section{HSP27, a heat shock protein family has a role in the maintenance of CSCs/CICs}

A previous study described that HSP27 has a role in the resistance to apoptosis induced by hypoxia or serum depletion in $\mathrm{CD}_{133^{+}}$colon cancer-initiating cells [18]. And, other study revealed that HSP27 protein expression is related to poorer prognosis in glioma cases [19]. We therefore focused on HSP27, and analyzed its function in gynecologic CSCs/CICs. HSP27 protein downregulation by HSP27-specific siRNAs were confirmed by a Western blot (Figure 3A). HSP27 protein knockdown reduced the frequency of $\mathrm{ALDH}^{\text {high }}$ cells and sphere-forming ability compared with control siRNA transfected HEC-1 cells (Figure 3B and 3C). These results indicate that HSP27 has a role in the maintenance of CSCs/CICs.

\section{Stress-activated transcription factor HSF1 works upstream of HSP27}

Since the expression of HSP27 is positively regulated by stress responsive transcription factor HSF1, we thus hypothesized that HFS1 is activated in CSCs/ CICs [20]. The expression of HSF1 mRNA was addressed by qRT-PCR, and there were no differences between expression levels in $\mathrm{ALDH}^{\text {high }}$ cells and $\mathrm{ALDH}^{\text {low }}$ cells (Figure 4A). The protein expression levels of HSF1 in $\mathrm{ALDH}^{\text {high }}$ cells an $\mathrm{ALDH}^{\text {low }}$ cells did not show significant differences (Figure 4B). HSF1 is phosphorylated at numbers of serine residues during cellular stress, and phosphorylation at Ser230 and Ser326 are essential for activation of HSF1 [21, 22]. We thus addressed the levels of phosphor HSF1 levels using phosho-HSF1 specific antibodies (pSer326, pSer320, pSer230, pSer303 and pSer307). HSF1 pSer326 were significantly increased in $\mathrm{ALDH}^{\text {high }}$ cells than that in $\mathrm{ALDH}^{\text {low }}$ cells derived from both HEC-1 cells and MCAS cells; however, other phosphorylation sites including Ser230 did not show any differences (Figure 4B). Immunohistochemical staining revealed that tumors derived from $\mathrm{ALDH}^{\text {high }}$ cells show higher phosphorylation at Ser326, whereas the protein expression levels of HSF1 did not show any difference in tumors derived from $\mathrm{ALDH}^{\text {high }}$ cells and $\mathrm{ALDH}^{\text {low }}$ cells (Figure 4C). To confirm the function of HSF1 pSer326, several HSF1 mutants were constructed. Ser230, Ser303, Ser307, Ser320 and Ser326 residues were substituted to alanine (A) or glutamic acid (E) to mimic non-phosphorylated status and phosphorylated status, respectively. HEC-1 cells were transfected with HSF1 mutants and stable transformants were established. The total HSF1 expression levels were confirmed by a Western blot (Figure 4D). HSP27 protein expression was increased by S303E, S320E and S326E overexpression. On the other hand, HSP27 protein expression was decreased by S307A and S326A overexpression. These observations indicate that phosphorylation of HSF1 at serine 326 residue is essential in the transcription of HSP27, and phosphorylation at serine 303 and 320 residues might have roles in the transcription of HSP27.

\section{Phosphorylation of HSF1 at Ser326 is related to the maintenance of CSCs/CICs and poorer prognosis}

To address the functions of HSF1, we performed gene knockdown and overexpression of HSF1. HSF1 was specifically knocked down using 2 different HSF1 specific siRNAs and knockdown was confirmed by Western blot (Figure 5A). HSF1 pSer326 and HSP27 were also decreased by HSF1 knockdown (Figure 5A). The rates of $\mathrm{ALDH}^{\text {high }}$ cells and sphere-forming ability were decreased by HSF1 knockdown (Figure 5B and 5C). On the other hand, the levels of HSF1 pSer326 and HSP27, the rates of $\mathrm{ALDH}^{\text {high }}$ cells and sphere-forming ability were increased by HSF1 gene overexpression (Figure 5D-5F). These observations indicate that HSF1 pSer326 is related to the expression of HSP27 and is also related to the maintenance of CSCs/CICs. To further analysis the functions of HSF1 pSer326, we examined the CSC/CIC frequencies of HEC-1 cell overexpressed HSF1 mutants by limiting dilution assay. Stable transformants of HEC-1 cells with S303A, S303E, S320A, S320E, S326A and S326E mutant were addressed, and only S326E overexpressed HEC-1 cells showed statistically significant increase CSC/CIC frequency compared with negative control (Table 2). Overexpression of S326A showed tendency of decrease CSC/CIC frequency (Table 2). These results indicate that HSF 1 phosphorylation at serine 326 is essential for the maintenance of CSCs/CICs.

To address the clinical significance of HSF1 pSer326, a total 122 of epithelial ovarian cancer tissues were immunohistochemically stained with anti-phosphoHSF1 (pSer326) rabbit polyclonal antibody (patients clinicopathological status is summarized in Supplementary Table 3). We divided into three groups (Figure 5G): Score 0 (HSF1 pSer326 positivity; <25\%, $n=41$ ), Score 1 (HSF1 pSre326 positivity; 25\%-68\%, $n=40$ ) and Score 2 (HSF1 pSer326 positivity; $>68 \%, n=41$ ). As summarized in Supplementary Table 3, there was no significant correlation between expression level of pHSF1, and age. FIGO clinical stage was significantly correlated with HSF1 (pSer326) expression. The univariate analysis revealed that HSF1 pSer326 score 1 or score 2, advanced FIGO stage, platinum resistant and optimal debulking surgery are significantly correlated with poorer prognosis (Table 3). However, only platinum resistant and optimal 
debulking surgery are correlated with poorer prognosis by multivariate analysis. Log-rank test revealed that higher expression of HSF1 pSer326 (Score1 and Score 2) are associated with poorer prognosis with a significant difference than those of lower expression levels of HSF1 pSer326 ( $P=0.0095)$ (Figure 5H). Higher expression levels of phosphor-HSF1 (pSer326) showed tendency with shorter overall survival (OS) than those of lower expression levels.

\section{DISCUSSION}

Cancer stem-like cells (CSCs)/ cancer-initiating cells (CICs) are resistant to anticancer drugs and radiotherapy and they can survive therapies. Therefore, we suspect that $\mathrm{CSCs} / \mathrm{CICs}$ have a high stress tolerance compared to

A

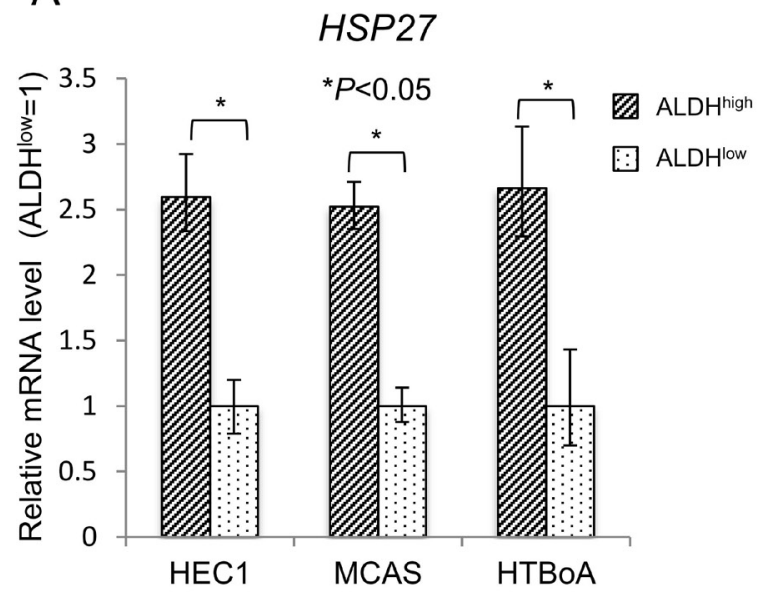

C

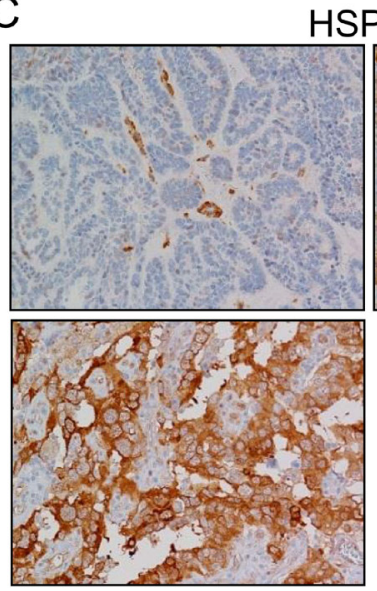

HSP27

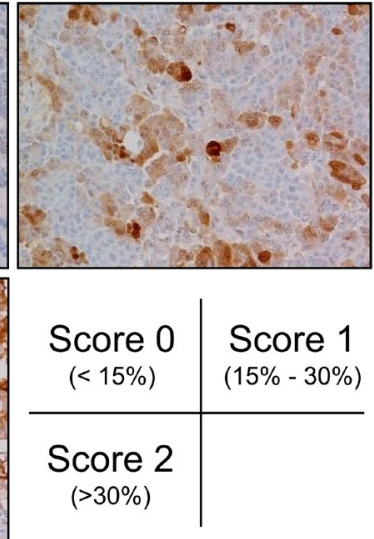

that of non-CSCs/CICs. In this study, we investigated the molecular mechanism of the gynecological CSCs/CICs isolated as $\mathrm{ALDH}^{\text {high }}$ cells, and found $\mathrm{CSCs} / \mathrm{CICs}$ have distinctive stress response mechanisms. Identification of rare subpopulations of cancer stem cells has created a new focus in cancer research in recent years, and gynecological CSCs/CICs have successfully isolated by using several markers; cell surface antigens [23, 24], and side population (SP) cells $[25,26]$ and Aldefluor assay $[15,27]$. Overlapping subpopulation of $\mathrm{ALDH}^{\text {high }}$ and SP cells showed higher tumor-initiating ability compared with $\mathrm{ALDH}^{\text {high }}$ cells and SP cells indicating that those markers of CSCs/CICs are not definite CSC/CIC marker [16].

ALDH1 belongs to the ALDH family of enzymes that metabolize aldehydes to carboxylic acids. Aldehyde dehydrogenases (ALDHs) oxidize aldehydes to the

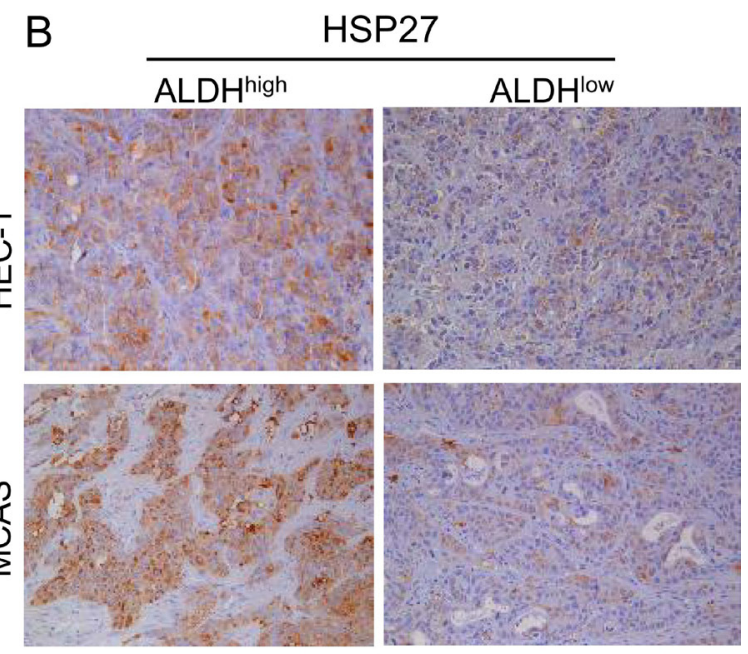

D

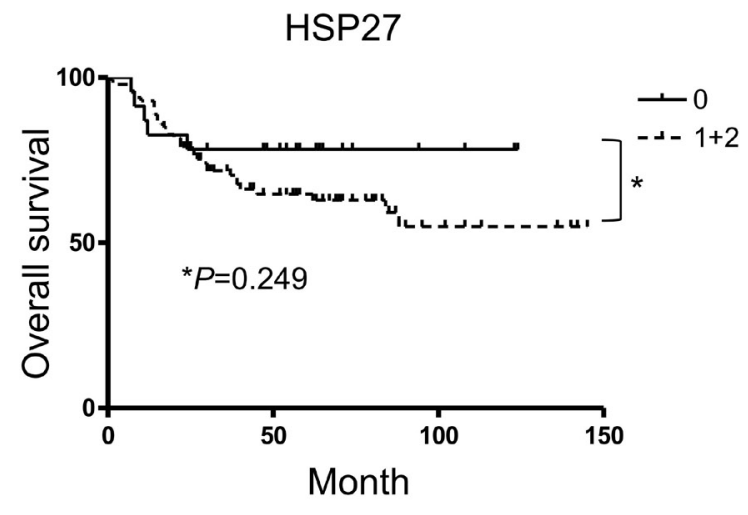

Figure 2: HSP27 expressed in ALDH1 ${ }^{\text {high }}$ cells derived from endometrial and ovarian carcinoma. (A) HSP27 expression by qRT-PCR. HSP27 expression was assessed by real-time PCR using ALDH1 ${ }^{\text {high }}$ and ALDH1 ${ }^{\text {low }}$ cells derived from HEC-1, MCAS and HTBoA cells. Data represent means \pm SD. ${ }^{*} P$ values. (B) The expression of HSP27 in tumors derived from ALDHhigh cells and ALDHlow cell. Tumors derived from ALDH1 ${ }^{\text {high }}$ cells and ALDH1 ${ }^{\text {low }}$ cells in HEC-1 and MCAS cells were immunohistochemically stained by HSP27 antibody. Magnification $\times 200$. (C) The expression of HSP27 in clinical samples. HSP27 protein expression was addressed using antiHSP27 antibody. Total of 122 ovarian cancer cases were immunohistochemically stained. The expressions of HSP27 were evaluated as (score 0: $<15 \%, n=40$; score 1: 15\%-30\%,n=41; score 2: $>30 \%, n=41$ ). (D) Overall survival. The differences of overall survival were examined for statistical significance using Fischer's test. ${ }^{*} P$ values. 
Table 2: Stem cell frequency of HSF1 mutant overexpressed HEC1 cells

\begin{tabular}{|c|c|c|c|c|c|c|c|}
\hline \multirow[t]{2}{*}{ Cells } & \multicolumn{4}{|c|}{ sphere-positive wells/total wells } & \multirow{2}{*}{$\begin{array}{c}\text { CSC } \\
\text { frequency }\end{array}$} & \multirow[t]{2}{*}{$95 \% \mathrm{CI}$} & \multirow[t]{2}{*}{${ }^{\dagger}$ v value } \\
\hline & $\begin{array}{c}1 \text { cell/ } \\
\text { well }\end{array}$ & $\begin{array}{c}10 \text { cells } \\
\text { /well }\end{array}$ & $\begin{array}{l}100 \text { cells/ } \\
\text { well }\end{array}$ & $\begin{array}{c}1000 \text { cells } \\
\text { /well }\end{array}$ & & & \\
\hline S303A & $0 / 48$ & $2 / 48$ & $21 / 48$ & $48 / 48$ & 1 in 175 & $121.3-252$ & 0.64 \\
\hline S303E & $0 / 48$ & $3 / 48$ & $16 / 48$ & $48 / 48$ & 1 in 212 & $148.3-304$ & 0.78 \\
\hline S320A & $0 / 48$ & $7 / 48$ & $18 / 48$ & $48 / 48$ & 1 in 168 & $116.3-242$ & 0.524 \\
\hline S320E & $0 / 48$ & $4 / 48$ & $21 / 48$ & $48 / 48$ & 1 in 163 & $112.7-235$ & 0.45 \\
\hline S326A & $2 / 48$ & $4 / 48$ & $10 / 48$ & $48 / 48$ & 1 in 246 & $174.2-349$ & 0.382 \\
\hline S326E & $3 / 48$ & $5 / 48$ & $25 / 48$ & $48 / 48$ & 1 in 118 & $82.9-167$ & $0.039 *$ \\
\hline WT & $0 / 48$ & $6 / 48$ & $27 / 48$ & $46 / 48$ & 1 in 173 & $119.7-249$ & 0.576 \\
\hline Mock & $0 / 48$ & $5 / 48$ & $20 / 48$ & $47 / 48$ & 1 in 197 & $137.4-284$ & \\
\hline
\end{tabular}

"Defference with Mock cells were caliculated by Chi-square test. " $P<0.05$.

corresponding carboxylic acids using either NAD or NADP as a coenzyme. Aldehydes are highly reactive aliphatic or aromatic molecules that play an important role in numerous physiological, pathological, and pharmacological processes. ALDH1 has been found in practically all organisms, and there are multiple isoforms with multiple subcellular localizations [28]. The ALDH family consists of 25 iso-enzymes, and ALDH1 can convert retinol to retinoic acid [28]. ALDH1 thus had been suggested to play a role in the expression of normal tissue stem cells through oxidation of retinol to control stem cell differentiation [29]. ALDH1 expression is increased in hematopoietic, neuronal, mesenchymal, endothelial and progenitor cells [29-31]. ALDHs have roles in anti-stress responses including oxidative stress and UV radiation, and now ALDH high active populations (ALDH ${ }^{\text {high }}$ cells) were well accepted as isolation of CSCs/CICs [32]. In this study, we used Aldefluor assay for isolation of $\mathrm{ALDH}^{\text {high }}$ cells from gynecological cancers. ALDH ${ }^{\text {high }}$ cells showed higher tumor-initiating ability, sphere-forming ability and higher expressions of stem cell-related genes, indicating that $\mathrm{ALDH}^{\text {high }}$ cells are enriched with CSCs/CISs as previous reports described. Therefore, ALDH ${ }^{\text {high }}$ cells used in this study are reasonable source for analysis of CSCs/CICs.

In this study, we screened the genes expressed in CSCs/CICs by using a cDNA microarray. And we found that several genes related to stress responses are overexpressed in CSCs/CICs. In a previous study,

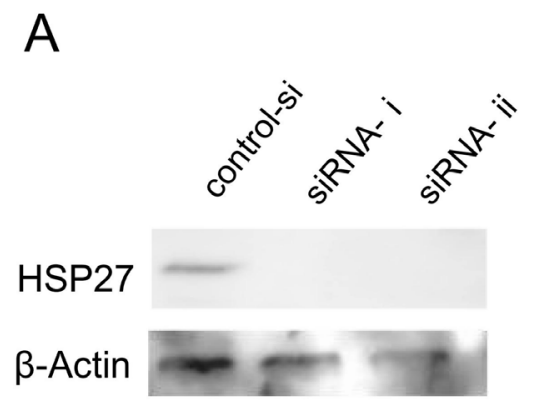

B

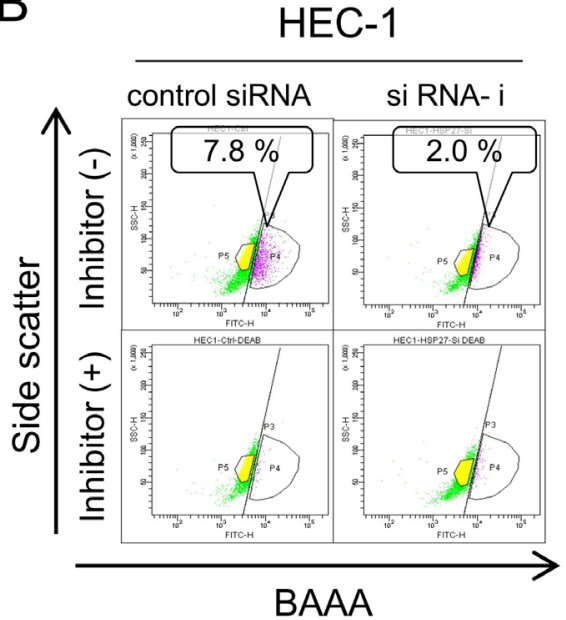

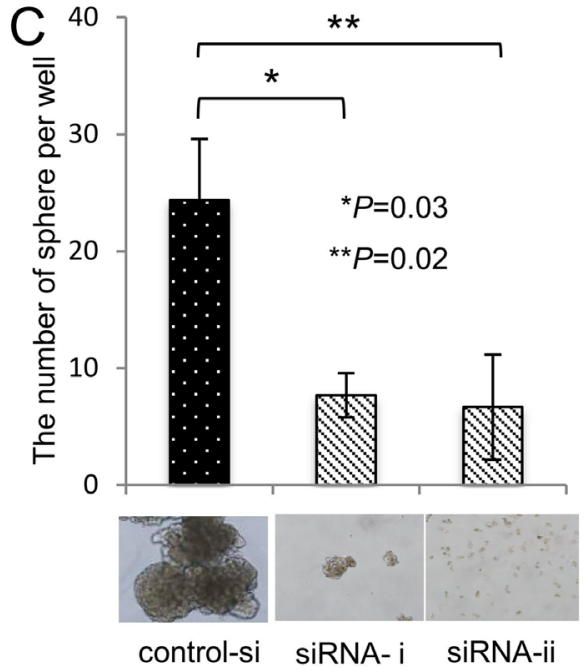

Figure 3: HSP27 has a role in the maintenance of CSCs/CICs. (A) Western blotting of HSP27 knockdown cells. HSP27 siRNA was transfected into HEC-1 cells. Twenty-four hours after transfection, total RNAs were purified and the expression of HSP27 was evaluated by Western blotting. $\beta$-actin was used as an internal control. (B) Aldefluor assay. ALDH activity of HSP27 knockdown cells was detected using the Aldefluor assay 48 hours after transfection. Percentage represents the proportion of ALDH1 ${ }^{\text {high }}$ cells. (C) Sphere formation assay. ALDH $1^{\text {high }}$ and ALDH $1^{\text {low }}$ cells derived from HSP27 SiRNA-transfected HEC1 cells were cultured in serum-free medium. After 2 weeks of culture in vitro, a picture of a tumor sphere was taken. The counts were examined for statistical significance using Student's $t$-test. Data represent means $\pm \mathrm{SD}$. $* P$ values. 
Table 3: Summary of univariate analysis and multivariate analysis of overall survival

Total cases $(n=122)$

\begin{tabular}{|c|c|c|c|c|}
\hline \multirow[t]{2}{*}{ Factor } & \multicolumn{2}{|c|}{ Univariate analysis } & \multicolumn{2}{|c|}{ Multivariate analysis } \\
\hline & $\begin{array}{c}\text { Risk ratio label } \\
\text { (95\% confidence interval) }\end{array}$ & $P$ & $\begin{array}{c}\text { Risk ratio label } \\
\text { (95\% confidence interval) }\end{array}$ & $P$ \\
\hline \multicolumn{5}{|l|}{$\begin{array}{l}\text { HSF1(pSer326) expression } \\
(\text { Score } 0 \sim+2)\end{array}$} \\
\hline 0 & 1 & - & & \\
\hline 1 & $3.56(1.40-9.04)$ & $0.008 * *$ & & \\
\hline 2 & $3.57(1.41-9.08)$ & $0.007 * *$ & & \\
\hline Advanced age (over 50) & $1.78(0.82-3.87)$ & 0.14 & & \\
\hline Multipara $(\geqq 2)$ & $1.78(0.70-3.24)$ & 0.12 & & \\
\hline \multicolumn{5}{|l|}{ Histological subtype } \\
\hline Serous & $1.55(0.82-2.92)$ & 0.17 & & \\
\hline Cleacell & $0.81(0.40-1.63)$ & 0.55 & & \\
\hline Endometrioid & $0.50(0.16-1.64)$ & 0.26 & & \\
\hline Mucinous & $0.97(0.23-4.02)$ & 0.97 & & \\
\hline $\begin{array}{l}\text { Advanced Stage } \\
\text { (over FIGO Stage III) }\end{array}$ & $8.02(2.85-22.59)$ & $<0.001 * *$ & & \\
\hline Peritoneal dissemination & $4.73(1.93-9.90)$ & $<0.001 * *$ & & \\
\hline Lymph node metastasis & $1.48(0.78-2.81)$ & 0.23 & & \\
\hline Platinum resistant & $12.46(5.18-29.96)$ & $<0.001 * *$ & $7.35(2.72-19.87)$ & $<0.001 * *$ \\
\hline Optimal debulking surgery & $0.14(0.07-0.30)$ & $<0.001^{* *}$ & $0.40(0.17-0.94)$ & $0.04^{*}$ \\
\hline
\end{tabular}

we showed that stress responsive signal transduction kinase MAPK13 is overexpressed in CSCs/CICs [14]. Gene knock down of MAPK13 significantly decreased tumor-initiation ability and sphere-forming ability, thus MAPK13 has a role in the maintenance of $\mathrm{CSCs} / \mathrm{CICs}$. In this study, we further focused on small heat shock protein family HSP27. Several HSP families have been described to tumor development, and HSP27 is also the case [33]. A recent study reported that breast CSCs/CICs isolated as $\mathrm{ALDH}^{\text {high }}$ cells or $\mathrm{CD} 44^{+} \mathrm{CD} 24$ cells showed higher HSP27 expressions and higher expressions of phosphorylated HSP27 [34]. They found that epithelialmesenchymal transition (EMT) and activation of NF$\kappa \mathrm{B}$ signaling were related to HSP27 expression. The phenotypes of CSCs/CICs could be inhibited by an HSP27 inhibitor Qercetin or HSP27 specific gene knockdown using siRNAs. The other study identified HSP27 is overexpressed in CD133+ putative CSCs/CICs induced by hypoxia culture of colon cancer cells HT-29 [18]. They found that p38MAPK-MAPKAPK2 signaling has a role in the activation of HSP27. In this and our previous study, we also identified that both MAPK13 and HSP27 are preferentially expressed in CSCs/CICs. MAPK13-HSP27 signaling might also be activated in gynecological CSCs/CICs. Furthermore, a proteome analysis revealed that histological high grade of glioma cases were related to higher expressions of HSP27 protein [19]. In this study, we found that HSP27 is preferentially expressed in gynecological CSCs/CICs for the first time. HSP27 specific gene knockdown decreased the frequencies of $\mathrm{ALDH}^{\text {high }}$ cells and decreased the sphereforming ability. These findings indicate that HSP27 has essential role in the maintenance of gynecological CSCs/ CICs. The exact molecular mechanisms how HSP27 maintains gynecological $\mathrm{CSCs} / \mathrm{CICs}$ are still elusive; however, targeting HSP27 might be a novel approach to target treatment-resistant $\mathrm{CSCs} / \mathrm{CICs}$ and Quercetin is a possible candidate to target HSP27 [34]. A recent study revealed that HSP27 can be a target of cytotoxic T lymphocytes (CTLs), and HSP27-specific CTLs could recognize HSP27-positive myeloma cells [35]. Since chemotherapy-resistant $\mathrm{CSCs} / \mathrm{CICs}$ are susceptible to CTLs [36], CSCs/CICs-targeting immunotherapy using HSP27 might be feasible. And, our recent findings indicate the potencies of CSC/CIC-targeting immunotherapy [10, 37-39]. However, HSP27 is also expressed in other normal organs and immunological responses to HSP27 may cause autoimmune diseases [33].

HSP27 expression is induced by activation of a transcription factor HSF1. In activation of HSF1, it undergoes trimerization and is localized to nucleus. HSF1 is phosphorylated at several residues under heat 
shock [40]. In normal cells, HSF1 regulates the various balance and homeostasis of cells. HSF1 and HSF2 play roles in spermatogenesis [41] and maintenance of the olfactory epithelium [42]. Recent studies described that HSF1 is also associated with carcinogenesis and poor prognosis $[33,43,44]$ In this study, we showed that HSF1 down-regulation and HSF1 overexpression affect sphereformation ability under non-stress conditions. These results indicate that HSF1 has a role in the maintenance of $\mathrm{CSCs} / \mathrm{CICs}$ regardless of stress. Human HSF1 is
A

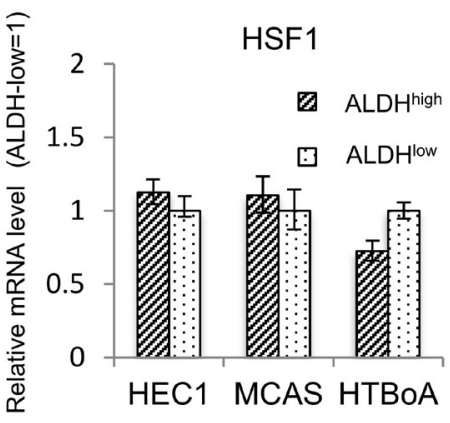

$\mathrm{B}$

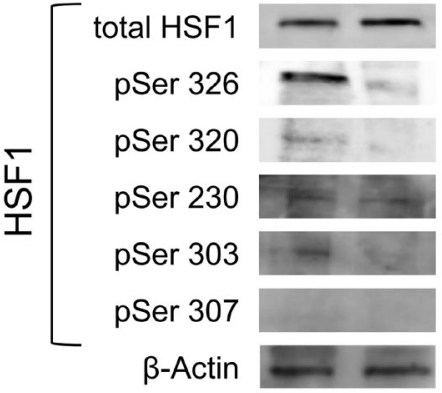

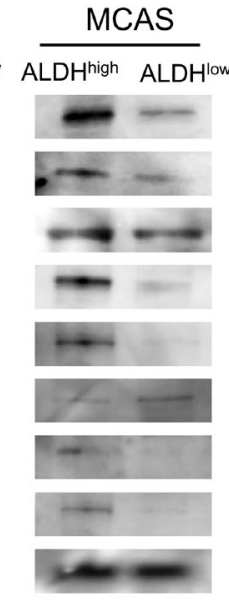

MCAS

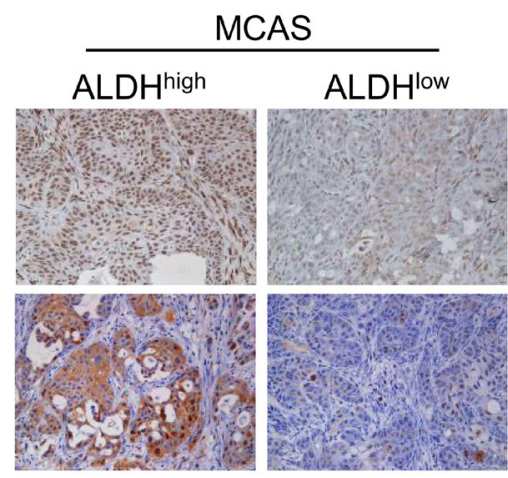

D
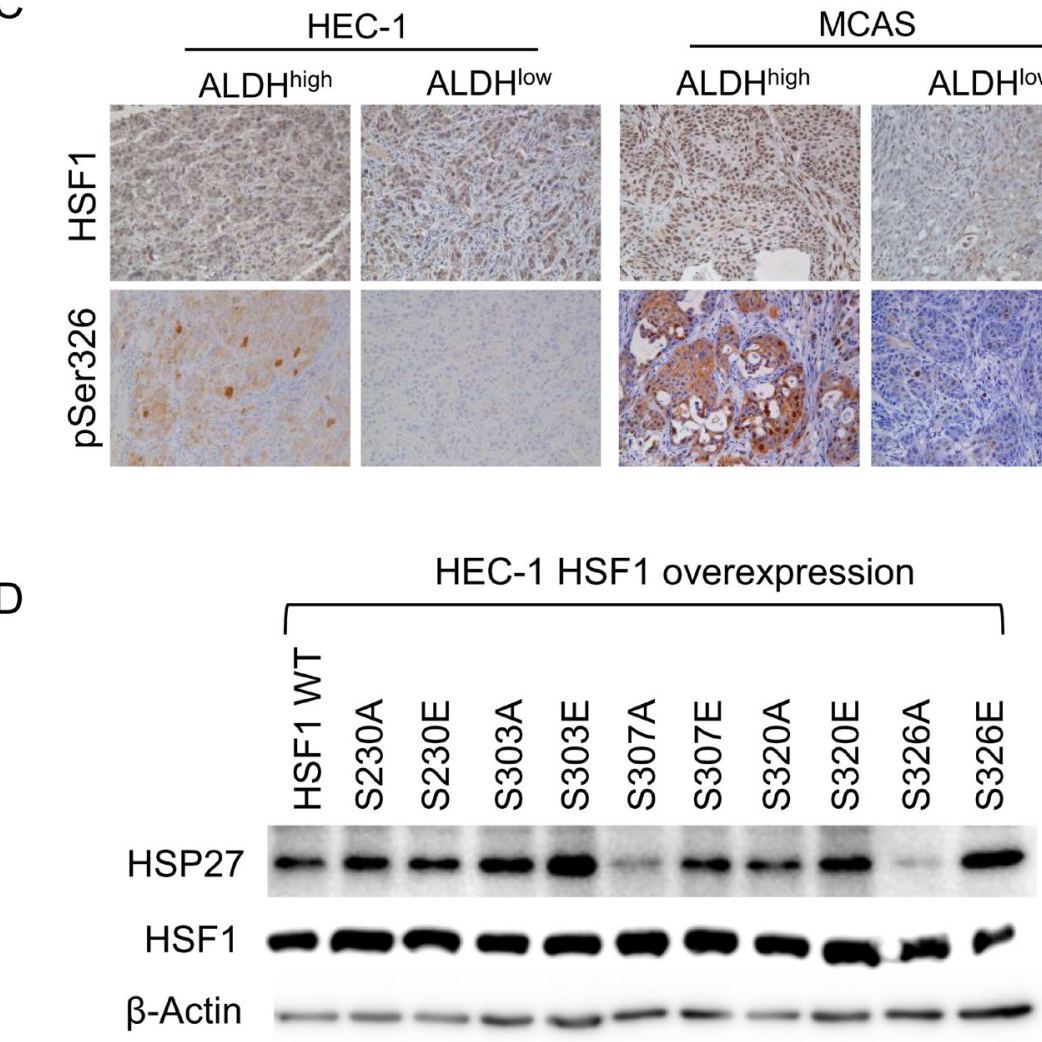

Figure 4: Stress-activated transcription factor HSF1 works upstream of HSP27. (A) HSF1 expression by qRT-PCR analysis. HSF1 expression was assessed by qRT-PCR using ALDH1 ${ }^{\text {high }}$ and ALDH $1^{\text {low }}$ cells derived from HEC-1, MCAS and HTBoA cells. GAPDH was used as an internal control. (B) Western blotting analysis. ALDH1 ${ }^{\text {high }}$ cells and ALDH1 $1^{\text {low }}$ cells in HEC-1 and MCAS cells were used. The expression of ALDH1, HSP27, HSF1 and phospho-HSF1 (pSer326, pSer320, pSer230, pSer303 and pSer307) was evaluated by Western blotting. $\beta$-actin was used as an internal control. (C) Immunohistochemical findings of Ser326-phosphorylated HSF1. Tumors derived from ALDH $1^{\text {high }}$ cells and ALDH1 $1^{\text {low }}$ cells of HEC-1 and MCAS cells were immunohistochemically stained using anti-phosphoHSF1 (pSer326) antibody and anti-HSF1 antibody. Magnification $\times 200$. (D) Expressions of HSP27 in HSF1 mutants overexpressed HEC-1 cells. HEC-1 cells were overexpressed with HSF1 wild type (WT) and mutants (S230A, S230E, S303A, S303E, S307A, S307E, S320A, S320E, S326A and S326E). The expression of HSP27 protein and total HSF1 were analyzed by Western blots. $\beta$-actin was used as an internal control. 

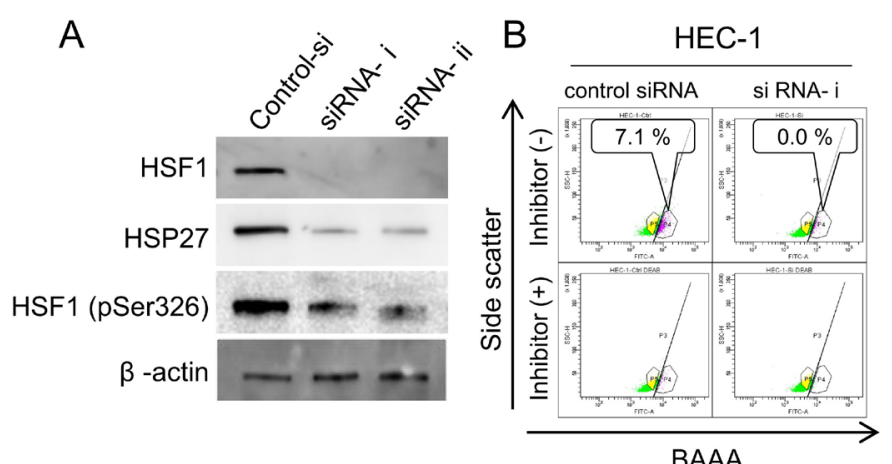

D

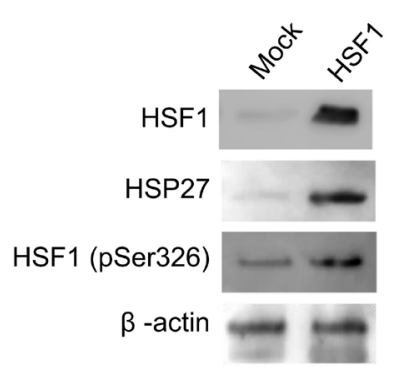

E

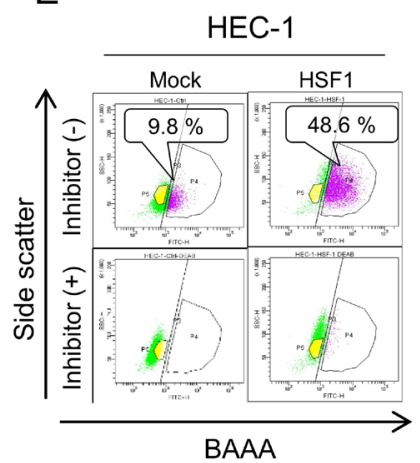

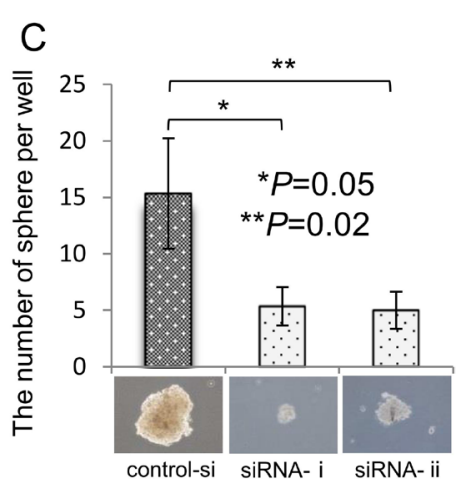

$\mathrm{F}$

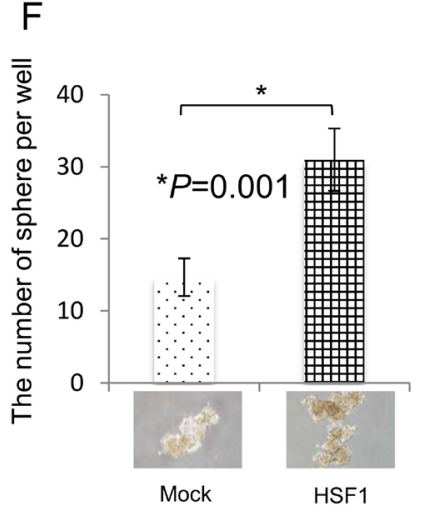

G

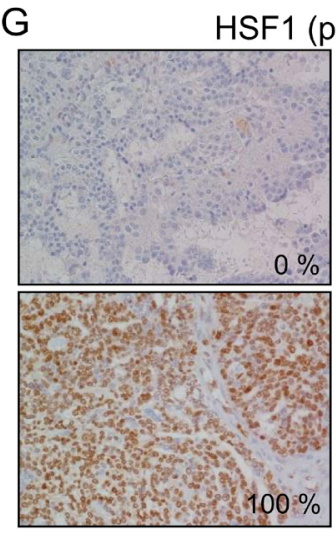

$\mathrm{H}$
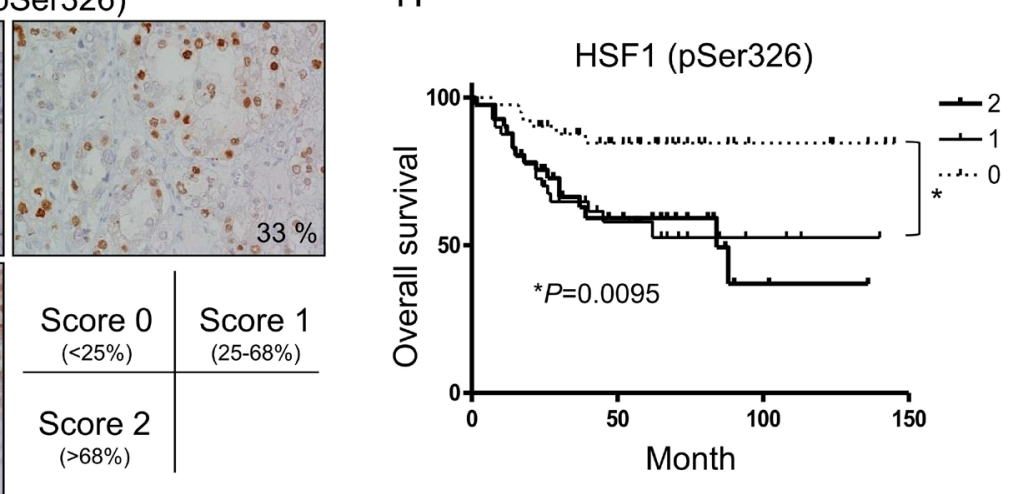

Figure 5: Phosphorylation of HSF1 at Ser326 is related to the maintenance of CSCs/CICs and poorer prognosis. (A) Western blotting of HSF1 knockdown cells. HSF1 siRNA was transfected into HEC-1 cells. Twenty-four hours after transfection, total RNAs were purified and the expression of HSF1, HSF1 pSer326 and HSP27 were evaluated by Western blotting. $\beta$-actin was used as an internal control. (B) Aldefluor assay. ALDH activity of HSF1 knockdown cells was detected using the Aldefluor assay 48 hours after transfection. Percentage represents the proportion of ALDH1 $1^{\text {high }}$ cells. (C) Sphere formation assay. ALDH1 ${ }^{\text {high }}$ and ALDH1 $1^{\text {low }}$ cells derived from HSF1 siRNA-transfected HEC1 cells were cultured in serum-free medium. After 2 weeks of culture in vitro, a picture of a tumor sphere was taken. The counts were examined for statistical significance using Student's $t$-test. Data represent means \pm SD. * $P$ values. (D) Western blotting of HSF1-overexpressed cells. Cells stably transfected with HSF1 and control vector-transfected cells were used. The expression of HSF1, HSF1 pSer326 and HSP27 were evaluated by Western blotting. $\beta$-actin was used as an internal control. (E) Aldefluor assay. ALDH activity of HSF1-overexpressed cells was detected using the Aldefluor assay 48 hours after transfection. Percentage represents the proportion of ALDH $1^{\text {high }}$ cells. (F) Sphere formation assay. ALDH $1^{\text {high }}$ and ALDH $1^{\text {low }}$ cells derived from HSF1overexpressed HEC1 cells were cultured in serum-free medium. After 2 weeks of culture in vitro, a picture of a tumor sphere was taken. The counts were examined for statistical significance using Student's $t$-test. Data represent means \pm SD. $* P$ values. (G) Immunohistological staining of phosphoHSF1 (pSer326). A total 122 of epithelial ovarian cancer tissues were immunohistochemically stained with anti-phophoHSF1 pSer326 antibody and the expressions of HSF 1 pSer326 were evaluated as (score 0: $<25 \%, n=41$; score 1: $25 \%-68 \%, n=40$; score 2: $>68 \%, n=41)$. Representative pictures are shown. The HSF 1 pSer 326 positive rates are $0 \%, 33 \%$ and $100 \%$, respectively. Magnification $\times 200$. (H) HSF1 pSer326 positive cases are associated with poor prognosis. The differences of overall survival were examined for statistical significance using Fischer's test. ${ }^{*} P$ values. 
phosphorylated on transactivation sites and transrepression sites [22]. Our results showed that the HSF1 protein was phosphorylated at Ser326 residue in ALDH1 ${ }^{\text {high }}$ cells and has a role in transcription of HSP27 and maintenance of CSCs/CICs. IHC staining showed that high expression of HSF 1 pSer326 is related to poorer prognosis by univariate analysis. However, multivariate analysis revealed that only Platinum resistant and Optimal debulking surgery are related to poorer prognosis. Since activation of HSF1 is related to stress-resistance including resistance to platinum, platinum resistance might diminished the phosphorylated HSF1 as an independent prognostic factor.

A recent study demonstrated that the kinase mTOR has a role in regulating the stress response and HSF1 phosphorylation on Ser326 [45]. And PI3K/AKT/mTOR signaling is activated in CSCs/CICs and mTOR is thought to be a molecular target of CSC/CIC-targeting therapy [46]. Thus, activated mTOR might phosphorylate HSF1 at Ser326 residue and induce the expression of HSP27 in CSCs/CICs, and mTOR, HSF1 and HSP27 might be candidates for CSC/CIC-targeting therapy.

In summary, we identified several stress-responsive genes are up-regurated in gynecological CSCs/CICs. Among stress-responsive gene products, HSP27 has a role in the maintenance of $\mathrm{CSCs} / \mathrm{CICs}$. HSF1 a transcription factor of HSP27 is activated in CSCs/CICs by phosphorylation at Ser326 residue. These results indicate that $\mathrm{CSCs} / \mathrm{CICs}$ have distinctive stress-response mechanisms that may related to treatment resistance. HSF1 and HSP27 might be novel targets to target treatment resistant $\mathrm{CSCs} / \mathrm{CICs}$.

\section{MATERIALS AND METHODS}

\section{Ethics statement}

Mice were maintained and experimented on in accordance with the guidelines of and after approval by the Committee of Sapporo Medical University School of Medicine, Animal Experimentation Center under permit number 08-006. Any animal found unhealthy or sick was promptly euthanized. All studies were approved by the Institutional Review Board (IRB) of Sapporo Medical University Hospital. Written informed consent was obtained from all patients according to the guidelines of the Declaration of Helsinki.

\section{Cell lines and cell culture}

Human endometrial carcinoma cells (HEC-1 cells) and human ovarian cells (MCAS and HTBoA cells) were obtained from ATCC (Manassas, VA, USA). HEC-1 and MCAS cells were maintained in Minimum Essential medium (MEM) (Life Technologies, Grand Island, NY, USA). HTBoA cells were maintained in Dulbecco's modified Eagle's medium (DMEM) (Sigma-Aldrich, St Louis, MO, USA). Each cell line was supplemented with $10 \% \mathrm{FBS}$ and cultured in a humidified 5\% CO2 incubator at $37^{\circ} \mathrm{C}$.

\section{Aldefluor assay}

The Aldefluor assay (Stem Cell Technologies ${ }^{\mathrm{TM}}$, Vancouver, BC, Canada) was performed to determine $\mathrm{ALDH}^{\text {high }}$ cells as described previously $[15,16]$. Briefly, cells were counted and suspended in assay buffer containing $1 \mu \mathrm{M}$ per $1 \times 10^{6}$ cells of the ALDH substrate, borondipyrrometheneaminoacetaldehyde (BAAA), and incubated for $50 \mathrm{~min}$ at $37^{\circ} \mathrm{C}$. Each sample was treated with $50 \mathrm{nM}$ of an ALDH-specific inhibitor, diethylaminobenzalydehyde (DEAB), as a negative control. BAAA-stained cells were analyzed and sorted using BD FACSAria ${ }^{\mathrm{TM}}$ II (BD Biosciences, San Jose, CA, USA).

\section{Sphere formation assay}

Sphere forming assay using ALDH ${ }^{\text {high }}$ cells, ALDH $^{\text {low }}$ cells, HSP27 siRNA transfected cells, HSF1 siRNA transfected cells and HSF1 plasmid transfected cells were performed as described previously [17]. Briefly, a total of 1,000 cells derived from HEC-1 cells were incubated in CSC Certified ${ }^{\mathrm{TM}}$ Complete Serum-Free Medium (Cell Systems Corporation, Kirkland, WA) in an Ultra-Low Attachment Surface culture 6-well plate $\left(\right.$ Corning $\left.^{\circledR}\right)$, and the number of spheres over $50 \mu \mathrm{m}$ in diameter was counted under light microscopy.

For estimation of CSC/CIC frequencies, limiting dilution analysis was performed. Serially diluted HSF1 wild type or mutant (S303A, S303E, S320A, S320E, S326A and S326E) overexpressed HEC-1 cells were seeded into 96-well Ultra-Low Attachment Plate $\left(\right.$ Corning $\left.^{\circledR}\right)$ in sphere-forming medium for 14 days. Then sphere-forming wells were counted and estimated frequencies of CSC/CIC were calculated at ELDA web site (http://bioinf.wehi.edu.au/software/elda/) [47].

\section{Xenograft transplantation}

Sorted cells were collected and re-suspended at the concentrations of $10^{2}-10^{4}$ cells per $50 \mu \mathrm{l}$ of PBS and mixed with $50 \mu \mathrm{l}$ of matrigel (BD Biosciences). The cell-matrigel mixture was subcutaneously injected in the subcutaneous spaces of 6-week-old non-obese diabetic/severe combined immune - deficiency (NOD/SCID) mice (NOD.CB17Prdkcscid/J, Charles River Laboratory, Yokohama, Japan) under anesthesia. Tumor growth was monitored weekly, and tumor volume was calculated by $\mathrm{XY}^{2} / 2(\mathrm{X}=$ long axis, $\mathrm{Y}=$ short axis). For the estimation of frequencies of CSCs/CICs ELDA web site (http://bioinf.wehi.edu.au/ software/elda/) was used [47]. 


\section{Gene expression profiling using cDNA microarrays}

RNAs from $\mathrm{ALDH}^{\text {high }}$ cells were labeled with Cy5 dye and those from ALDH ${ }^{\text {low }}$ cells were labeled with Cy3 dye and cDNA microarray using Human Panorama Micro Array (Sigma-Aldrich) was performed as described previously [48]. A dye-swap experiment (labeling $\mathrm{ALDH}^{\text {high }}$ cells and $\mathrm{ALDH}^{\text {low }}$ cells with $\mathrm{Cy} 3$ and Cy5, respectively) was also performed. Microarray raw data have been deposited in the Array Express data-base (E-MTAB-4440).

\section{Reverse transcription-polymerase analysis (RT-PCR) analysis and Quantitative real-time RT-PCR analysis (qRT-PCR)}

Isolation of RNA and RT-PCR analysis were performed as described previously [49]. The thermal cycling conditions were $94^{\circ} \mathrm{C}$ for $2 \mathrm{~min}$, followed by 35 cycles of $15 \mathrm{sec}$ at $94^{\circ} \mathrm{C}, 30 \mathrm{sec}$ at $60^{\circ} \mathrm{C}$, and $30 \mathrm{sec}$ at $72^{\circ} \mathrm{C}$. GAPDH was used as an internal positive control. The primers used in experiments are summarized in Supplementary Table 1.

Quantitative real-time PCR was performed using the ABI PRISM 7000 Sequence Detection System (Applied Biosystems, Foster City, CA) according to the manufacturer's protocol. HSP27 (Hs03044127_g1) and HSF1 (Hs00232134_m1) primers and probes were designed by the manufacturer (TaqMan Gene expression assays; Applied Biosystems). Thermal cycling was performed using 40 cycles of $95^{\circ} \mathrm{C}$ for 15 seconds followed by $60^{\circ} \mathrm{C}$ for $1 \mathrm{~min}$. Each experiment was done in triplicate, and the results were normalized to the GAPDH gene as an internal control.

\section{Western blotting analysis}

Western blotting was performed as described previously [50]. Briefly, $1 \times 10^{5}$ of $\mathrm{ALDH}^{\text {high }}$ cells and $\mathrm{ALDH}^{\text {low }}$ cells derived from HEC-1 cells, siRNA transfected HEC-1 cells and HSF1 plasmid transfected HEC-1 cells were lysed in $100 \mu$ of SDS sample buffer. Anti-ALDH1 mouse monoclonal antibody (clone: 44/ ALDH, BD Pharmingen) was used at 1000-times dilution. Anti-HSP27 rabbit polyclonal antibody (Abcam, Cambridge, UK), anti-HSF1 rabbit polyclonal antibody (Sigma-Aldrich, Saint Louis, MO), anti-HSF1 pSer320 rabbit polyclonal antibody (Abcam, Cambridge, UK), anti-HSF1 pSer326 rabbit polyclonal antibody (Abcam, Cambridge, UK), anti-HSF1 pSer230 rabbit polyclonal antibody (Santa cruz, Dallas, TX), anti-HSF1 pSer303 rabbit polyclonal antibody (Sigma-Aldrich, Saint Louis, MO) and anti-HSF1 pSer307 rabbit polyclonal antibody (Santa cruz, Dallas, TX) were used at 1000-times dilution.
Anti- $\beta$-Actin mouse monoclonal antibody (Sigma-Aldrich, Saint Louis, MO) was used at 2000-times dilution. Antimouse $\operatorname{IgG}+\operatorname{IgM}$ and anti-rabbit IgG and IgM second antibodies (KPL) were uses at 2000-times dilution. The membrane was visualized with Chemiluminescent HRP Substrate (Milipore Corporation, Bilerica, MA) according to the manufacturer's protocol, and pictures were taken by an Odyssey ${ }^{\circledR}$ Fc Imaging System (LI-COR, Lincoln, NE).

\section{HSF-1 mRNA knockdown by siRNA}

To knockdown HSP27 and HSF-1 genes, HSP27 siRNAs (Hs_HSPB1_2074(i), Hs_HSPB1_2076(ii)) and HSF-1 siRNAs (Hs_HSF1_7735(i), Hs_HSF1_7746(ii)) were purchased from Life Technologies. Transfection of siRNA duplexes using Lipofectamine ${ }^{\mathrm{TM}}$ RNAiMAX (Life Technologies) was performed according to the protocol of the manufacturer. Cells were transfected with siRNA 48 hours before analysis. Negative control siRNA (Stealth RNAi Negative Control; Life Technologies) was used.

\section{HSF1 and HSF1 mutants' construction and overexpression}

Full-length HSF1 cDNA was amplified from cDNA of HEC-1 cells with PCR using KOD-Plus DNA polymerase (Toyobo, Osaka, Japan). The PCR product was inserted into pIRES-puro3 expression vector (TaKaRa Bio, Kusatsu, JAPAN). HSF1 mutants (S230A, S230E, S303A, S303E, S307A, S307E, S320A, S320E, S326A and S326E) were constructed by PCR mutagenesis using mutation-specific primers, and the sequences were confirmed by DNA sequencing. HSF1 and HSF1 mutants coding plasmid was transfected into HEC-1 cells using Lipofectamine ${ }^{\circledR} 2000$ Transfection Reagent (Life Technologies) according to manufacturer's protocol. Tresnfected cells were cultured in puromycin $(1 \mu \mathrm{g} / \mathrm{ml})$ containing growth medium until stable transformants were established.

\section{Immunohistochemical staining}

Immunohistochemical staining was performed with formalin-fixed, paraffin-embedded (FFPE) sections of tumors of human ovarian cancer cases and tumors derived from NOD/SCID mice as described previously [51]. Surgical specimens used for immunohistochemically staining were obtained from 122 patients with primary epithelial ovarian cancer who had been treated at Sapporo Medical University Hospital during the period from 2001 to 2011. Anti-ALDH1 monoclonal antibody (1:100, SigmaAldrich), rabbit anti-HSP27 polyclonal antibody (1:150, Abcam), rabbit anti-HSF1 polyclonal antibody (1:200, Sigma-Aldrich) and rabbit anti-HSF1 pSer326 polyclonal antibody (1:500, Abcam) were uses as 1st antibodies. 


\section{Statistical analysis}

Statistical analysis, data fitting and graphics were performed by SPSS software package ver.19 (SPSS, Chicago, IL, USA). Data was shown as the mean \pm SD of at least 3 independent experiments and Chi-square test was used to assess the statistical significant difference $(p<0.05)$. Overall survival (OS), which was defined as interval from the date of first diagnosis to the date of death of disease progression were estimated using Kaplan-Meier method and compared with the log-rank test.

\section{Abbreviations}

CSC, cancer stem-like cell; CIC, cancer-initiating cell; ALDH1, aldehyde dehydrogenese 1; HSP, heat-shock protein; HSF 1, heat-shock factor 1

\section{ACKNOWLEDGMENTS AND FUNDING}

This study was supported by a Grant-in-Aid for Scientific Research from the Ministry of Education, Culture, Sports, Science and Technology of Japan (to N. S.), program for developing the supporting system for upgrading education and research from the Ministry of Education, Culture, Sports, Science and Technology of Japan (to N. S.), Health and Labour Sciences Research Grants, a grant-in-aid of Ono Cancer Research Fund (to T. T.), Sagawa Foundation for Promotion of Cancer Research (to Y.H.), Suharakinenzaidan Co., Ltd. (to Y.H.) and Kobayashi foundation for cancer research (to Y.H.). This study was supported in part by Grants-in-Aid for Regional R\&D Proposal-Based Program from Northern Advancement Center for Science \& Technology of Hokkaido Japan (to Y.H. and T.T.).

\section{CONFLICTS OF INTEREST}

The authors have no financial conflict of interest.

\section{REFERENCES}

1. Reya T, Morrison SJ, Clarke MF, Weissman IL. Stem cells, cancer, and cancer stem cells. Nature. 2001; 414:105-111.

2. Clarke MF, Dick JE, Dirks PB, Eaves CJ, Jamieson CH, Jones DL, Visvader J, Weissman IL, Wahl GM. Cancer stem cells - perspectives on current status and future directions: AACR Workshop on cancer stem cells. Cancer Res. 2006; 66:9339-9344.

3. Clevers H. The cancer stem cell: premises, promises and challenges. Nature Med. 2011; 17:313-319.

4. Lapidot T, Sirard C, Vormoor J, Murdoch B, Hoang T, Caceres-Cortes J, Minden M, Paterson B, Caligiuri MA, Dick JE. A cell initiating human acute myeloid leukaemia after transplantation into SCID mice. Nature. 1994; 367:645-648.
5. Al-Hajj M, Wicha MS, Benito-Hernandez A, Morrison SJ, Clarke MF. Prospective identification of tumorigenic breast cancer cells. Proc Natl Acad Sci USA. 2003; 100:3983-3988.

6. Park CY, Tseng D, Weissman IL. Cancer stem cell-directed therapies: recent data from the laboratory and clinic. Mol Ther. 2009; 17:219-230.

7. Parsell DA, Lindquist S. The function of heat-shock proteins in stress tolerance: degradation and reactivation of damaged proteins. Annu Rev Genet. 1993; 27:437-496.

8. Tower J. Stress and stem cells. Wiley Interdiscip Rev Dev Biol. 2012; 1:789-802.

9. Li L, Bhatia R. Stem cell quiescence. Clin Cancer Res. 2011; 17:4936-4941.

10. Nishizawa S, Hirohashi Y, Torigoe T, Takahashi A, Tamura Y, Mori T, Kanaseki T, Kamiguchi K, Asanuma H, Morita R, Sokolovskaya A, Matsuzaki J, Yamada R, et al. HSP DNAJB8 Controls Tumor-Initiating Ability in Renal Cancer Stem-like Cells. Cancer Res. 2012; 72:2844-2854.

11. Mendillo ML, Santagata S, Koeva M, Bell GW, Hu R, Tamimi RM, Fraenkel E, Ince TA, Whitesell L, Lindquist S. HSF1 Drives a Transcriptional Program Distinct from Heat Shock to Support Highly Malignant Human Cancers. Cell. 2012; 150:549-562.

12. Yamashita M, Hirohashi $\mathrm{Y}$, Torigoe $\mathrm{T}$, Kusumoto $\mathrm{H}$, Murai A, Imagawa T, Sato N. Dnajb8, a Member of the Heat Shock Protein 40 Family Has a Role in the Tumor Initiation and Resistance to Docetaxel but Is Dispensable for Stress Response. PloS one. 2016; 11:e0146501.

13. Torigoe T, Hirohashi Y, Yasuda K, Sato N. Constitutive expression and activation of stress response genes in cancer stem-like cells/tumour initiating cells: potent targets for cancer stem cell therapy. Int J Hyperthermia. 2013; 29:436-441.

14. Yasuda K, Hirohashi Y, Kuroda T, Takaya A, Kubo T, Kanaseki T, Tsukahara T, Hasegawa T, Saito T, Sato N, Torigoe T. MAPK13 is preferentially expressed in gynecological cancer stem cells and has a role in the tumorinitiation. Biochem Biophys Res Commun. 2016; 472: 643-647.

15. Kuroda T, Hirohashi Y, Torigoe T, Yasuda K, Takahashi A, Asanuma H, Morita R, Mariya T, Asano T, Mizuuchi M, Saito T, Sato N. ALDH1-High Ovarian Cancer StemLike Cells Can Be Isolated from Serous and Clear Cell Adenocarcinoma Cells, and ALDH1 High Expression Is Associated with Poor Prognosis. PloS one. 2013; 8:e65158.

16. Yasuda K, Torigoe T, Morita R, Kuroda T, Takahashi A, Matsuzaki J, Kochin V, Asanuma H, Hasegawa T, Saito T, Hirohashi Y, Sato N. Ovarian cancer stem cells are enriched in side population and aldehyde dehydrogenase bright overlapping population. PloS one. 2013; 8:e68187.

17. Yasuda K, Torigoe T, Mariya T, Asano T, Kuroda T, Matsuzaki J, Ikeda K, Yamauchi M, Emori M, Asanuma H, Hasegawa T, Saito T, Hirohashi Y, et al. Fibroblasts induce expression of FGF4 in ovarian cancer stem-like cells/ cancer-initiating cells and upregulate their tumor initiation capacity. Lab Invest. 2014; 94:1355-69. 
18. Lin SP, Lee YT, Wang JY, Miller SA, Chiou SH, Hung MC, Hung SC. Survival of cancer stem cells under hypoxia and serum depletion via decrease in PP2A activity and activation of p38-MAPKAPK2-Hsp27. PloS one. 2012; 7:e49605.

19. Gimenez M, Marie SK, Oba-Shinjo S, Uno M, Izumi C, Oliveira JB, Rosa JC. Quantitative proteomic analysis shows differentially expressed HSPB1 in glioblastoma as a discriminating short from long survival factor and NOVA1 as a differentiation factor between low-grade astrocytoma and oligodendroglioma. BMC Cancer. 2015; 15:481.

20. Cooper LF, Uoshima K, Guo Z. Transcriptional regulation involving the intronic heat shock element of the rat hsp27 gene. Biochim Biophys Acta. 2000; 1490:348-354.

21. Holmberg CI, Hietakangas V, Mikhailov A, Rantanen JO, Kallio M, Meinander A, Hellman J, Morrice N, MacKintosh C, Morimoto RI, Eriksson JE, Sistonen L. Phosphorylation of serine 230 promotes inducible transcriptional activity of heat shock factor 1. EMBO J. 2001; 20:3800-3810.

22. Guettouche T, Boellmann F, Lane WS, Voellmy R. Analysis of phosphorylation of human heat shock factor 1 in cells experiencing a stress. BMC Biochem. 2005; 6:4.

23. Baba T, Convery PA, Matsumura N, Whitaker RS, Kondoh E, Perry T, Huang Z, Bentley RC, Mori S, Fujii S, Marks JR, Berchuck A, Murphy SK. Epigenetic regulation of CD133 and tumorigenicity of CD133+ ovarian cancer cells. Oncogene. 2009; 28:209-218.

24. Gao MQ, Choi YP, Kang S, Youn JH, Cho NH. CD24+ cells from hierarchically organized ovarian cancer are enriched in cancer stem cells. Oncogene. 2010; 29:2672-2680.

25. Szotek PP, Pieretti-Vanmarcke R, Masiakos PT, Dinulescu DM, Connolly D, Foster R, Dombkowski D, Preffer F, Maclaughlin DT, Donahoe PK. Ovarian cancer side population defines cells with stem cell-like characteristics and Mullerian Inhibiting Substance responsiveness. Proc Natl Acad Sci USA. 2006; 103:11154-11159.

26. Vathipadiekal V, Saxena D, Mok SC, Hauschka PV, Ozbun L, Birrer MJ. Identification of a potential ovarian cancer stem cell gene expression profile from advanced stage papillary serous ovarian cancer. PloS one. 2012; 7:e29079.

27. Wang YC, Yo YT, Lee HY, Liao YP, Chao TK, Su PH, Lai HC. ALDH1-bright epithelial ovarian cancer cells are associated with CD44 expression, drug resistance, and poor clinical outcome. Am J Pathol. 2012; 180:1159-1169.

28. Yoshida A, Hsu LC, Dave V. Retinal oxidation activity and biological role of human cytosolic aldehyde dehydrogenase. Enzyme. 1992; 46:239-244.

29. Ma I, Allan AL. The role of human aldehyde dehydrogenase in normal and cancer stem cells. Stem Cell Rev. 2011; 7:292-306.

30. Storms RW, Green PD, Safford KM, Niedzwiecki D, Cogle CR, Colvin OM, Chao NJ, Rice HE, Smith CA. Distinct hematopoietic progenitor compartments are delineated by the expression of aldehyde dehydrogenase and CD34. Blood. 2005; 106:95-102.

31. Ginestier C, Hur MH, Charafe-Jauffret E, Monville F, Dutcher J, Brown M, Jacquemier J, Viens P, Kleer CG, Liu S, Schott A, Hayes D, Birnbaum D, et al. ALDH1 is a marker of normal and malignant human mammary stem cells and a predictor of poor clinical outcome. Free Radic Biol Med. 2007; 1:555-567.

32. Singh S, Brocker C, Koppaka V, Chen Y, Jackson BC, Matsumoto A, Thompson DC, Vasiliou V. Aldehyde dehydrogenases in cellular responses to oxidative/ electrophilic stress. Free radical biology \& medicine. 2013; 56:89-101.

33. Ciocca DR, Arrigo AP, Calderwood SK. Heat shock proteins and heat shock factor 1 in carcinogenesis and tumor development: an update. Arch Toxicol. 2013; 87:19-48.

34. Wei L, Liu TT, Wang HH, Hong HM, Yu AL, Feng HP, Chang WW. Hsp27 participates in the maintenance of breast cancer stem cells through regulation of epithelialmesenchymal transition and nuclear factor-kappaB. Breast Cancer Res. 2011; 13:R101.

35. Li R, Qian J, Zhang W, Fu W, Du J, Jiang H, Zhang H, Zhang C, Xi H, Yi Q, Hou J. Human heat shock proteinspecific cytotoxic T lymphocytes display potent antitumour immunity in multiple myeloma. Br J Haematol. 2014; 166:690-701.

36. Inoda S, Hirohashi Y, Torigoe T, Morita R, Takahashi A, Asanuma H, Nakatsugawa M, Nishizawa S, Tamura Y, Tsuruma T, Terui T, Kondo T, Ishitani K, et al. Cytotoxic $\mathrm{T}$ lymphocytes efficiently recognize human colon cancer stem-like cells. Am J Pathol. 2011; 178:1805-1813.

37. Morita R, Nishizawa S, Torigoe T, Takahashi A, Tamura Y, Tsukahara T, Kanaseki T, Sokolovskaya A, Kochin V, Kondo T, Hashino S, Asaka M, Hara I, et al. Heat shock protein DNAJB8 is a novel target for immunotherapy of colon cancer-initiating cells. Cancer Sci. 2014; 105:389-395.

38. Asano T, Hirohashi Y, Torigoe T, Mariya T, Horibe R, Kuroda T, Tabuchi Y, Saijo H, Yasuda K, Mizuuchi M, Takahashi A, Asanuma H, Hasegawa T, et al. Brother of the regulator of the imprinted site (BORIS) variant subfamily 6 is involved in cervical cancer stemness and can be a target of immunotherapy. Oncotarget. 2016; 7:11223-11237. doi: 10.18632/oncotarget.7165.

39. Hirohashi Y, Torigoe T, Tsukahara T, Kanaseki T, Kochin V, Sato N. Immune responses to human cancer stem-like cells/ cancer-initiating cells. Cancer Sci. 2016; 107:12-17.

40. Trinklein ND, Murray JI, Hartman SJ, Botstein D, Myers RM. The role of heat shock transcription factor 1 in the genome-wide regulation of the mammalian heat shock response. Mol Biol Cell. 2004; 15:1254-1261.

41. Wilkerson DC, Sarge KD. RNA polymerase II interacts with the Hspalb promoter in mouse epididymal spermatozoa. Reproduction. 2009; 137:923-929.

42. Takaki E, Fujimoto M, Sugahara K, Nakahari T, Yonemura S, Tanaka Y, Hayashida N, Inouye S, Takemoto T, Yamashita H, 
Nakai A. Maintenance of olfactory neurogenesis requires HSF1, a major heat shock transcription factor in mice. J Biol Chem. 2006; 281:4931-4937.

43. Dai C, Whitesell L, Rogers AB, Lindquist S. Heat shock factor 1 is a powerful multifaceted modifier of carcinogenesis. Cell. 2007; 130:1005-1018.

44. Santagata S, Hu R, Lin NU, Mendillo ML, Collins LC, Hankinson SE, Schnitt SJ, Whitesell L, Tamimi RM, Lindquist S, Ince TA. High levels of nuclear heat-shock factor 1 (HSF1) are associated with poor prognosis in breast cancer. Proc Natl Acad Sci USA. 2011; 108:18378-18383.

45. Chou SD, Prince T, Gong J, Calderwood SK. mTOR is essential for the proteotoxic stress response, HSF1 activation and heat shock protein synthesis. PloS one. 2012; 7:e39679.

46. Francipane MG, Lagasse E. Therapeutic potential of mTOR inhibitors for targeting cancer stem cells. Br J Clin Pharmacol. 2015; 82:1180-1188.

47. $\mathrm{Hu}$ Y, Smyth GK. ELDA: extreme limiting dilution analysis for comparing depleted and enriched populations in stem cell and other assays. J Immunol Methods. 2009; 347:70-78.

48. Takahashi A, Hirohashi Y, Torigoe T, Tamura Y, Tsukahara T, Kanaseki T, Kochin V, Saijo H, Kubo T, Nakatsugawa M, Asanuma H, Hasegawa T, Kondo T, et al.
Ectopically expressed variant form of sperm mitochondriaassociated cysteine-rich protein augments tumorigenicity of the stem cell population of lung adenocarcinoma cells. PloS one. 2013; 8:e69095.

49. Nakatsugawa M, Hirohashi $Y$, Torigoe $T$, Asanuma $H$, Takahashi A, Inoda S, Kiriyama K, Nakazawa E, Harada K, Takasu H, Tamura Y, Kamiguchi K, Shijubo N, et al. Novel spliced form of a lens protein as a novel lung cancer antigen, Lengsin splicing variant 4. Cancer Sci. 2009; 100:1485-1493.

50. Inoda S, Hirohashi $\mathrm{Y}$, Torigoe $\mathrm{T}$, Nakatsugawa $\mathrm{M}$, Kiriyama K, Nakazawa E, Harada K, Takasu H, Tamura Y, Kamiguchi K, Asanuma H, Tsuruma T, Terui T, et al. Cep55/c10orf3, a tumor antigen derived from a centrosome residing protein in breast carcinoma. J Immunother. 2009; 32:474-485.

51. Mariya T, Hirohashi Y, Torigoe T, Asano T, Kuroda T, Yasuda K, Mizuuchi M, Sonoda T, Saito T, Sato N. Prognostic impact of human leukocyte antigen class I expression and association of platinum resistance with immunologic profiles in epithelial ovarian cancer. Cancer Immunol Res. 2014; 2:1220-1229. 